\title{
Factors influencing consumer wine choice: The case of wine tourism
}

Margaret Connolly

Technological University Dublin, margaret.connolly@tudublin.ie

Follow this and additional works at: https://arrow.tudublin.ie/tschafbk

Part of the Food and Beverage Management Commons, Food Studies Commons, Leisure Studies Commons, Marketing Commons, Sales and Merchandising Commons, and the Tourism and Travel Commons

\section{Recommended Citation}

Connolly M. (2019) Factors Influencing Consumer Wine Choice: The Case of Wine Tourism. In: Sigala M., Robinson R. (eds) Management and Marketing of Wine Tourism Business. Palgrave Macmillan, Cham. https://doi.org/10.1007/978-3-319-75462-8_3

This Book Chapter is brought to you for free and open access by the School of Culinary Arts and Food Technology at ARROW@TU Dublin. It has been accepted for inclusion in Books/Book Chapters by an authorized administrator of ARROW@TU Dublin. For more information, please contact arrow.admin@tudublin.ie, aisling.coyne@tudublin.ie, gerard.connolly@tudublin.ie.

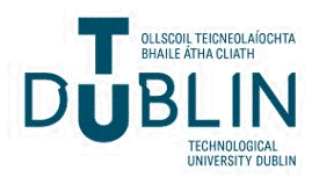


Factors Influencing Consumer Wine Choice - The Case of Wine Tourism Author: Margaret Connolly

MARGARET CONNOLLY margaret.connolly@tudublin.ie 


\begin{abstract}
This research was undertaken to examine the relationship between the wine tourism activities of consumers and their subsequent wine choices. Exploratory research was undertaken giving specific attention to wine tourism, firstly as a factor of influence on decision-making, secondly on levels of consumer involvement and thirdly on long term consumer loyalty. A convenience sample of 12 wine consumers in Dublin participated in the study. Semistructured in-depth interviews were used to gather the qualitative data used. The findings clearly establish links made by consumers between their wine tourism experiences and their subsequent wine purchase preferences. The findings highlight the importance of facilitating the co-creation of memorable wine tourism experiences as a determinant of improved consumer involvement as well as the development of long term consumer loyalty. Implications for industry practitioners suggest a continued focus on the provision of unique wine tourism experiences; while the findings support the theoretical links between consumers own past experiences and their use as a valuable information source when making purchase decisions.
\end{abstract}

\title{
Key words:
}

Wine tourism, Consumer decision-making, Consumer involvement, Consumer experience, Loyalty 


\section{Factors Influencing Consumer Wine Choice - The Case of Wine Tourism}

\section{Introduction}

There is an undeniable relationship between travel and the consumption choices made by society. It has been acknowledged throughout history how the movement of people from one end of the globe to the other has influenced people's diet (Jamal, 1996). The tourism industry has a continuing influence over national cuisines around the world and this phenomena has become increasing important when it comes to the influence of wine tourism. Brown and Getz (2005) suggest that for some wine lovers, travel in general has led to an interest in wine, whereas for others wine tourism follows naturally from a growing involvement with wine as part of their lifestyle.

The focus of this chapter is to investigate the role of wine tourism activities as a factor of influence in consumer wine choice. The literature reviewed draws from a number of related areas within wine tourism, tourism marketing and consumer behaviour.

\section{Consumption in the Twenty First Century}

As the nature of modern society has evolved from its initial industrial focus to that of a consumption oriented one (Featherstone, 2007; Baudrillard, 1998), consumers now continually look for and engage in consumption experiences across all aspects of their everyday lives. Involvement and immersion in these consumption experiences is perceived by many consumers as an integral part of living a fulfilled and modern liberated existence (Lindgreen et.al. 2009). Lifestyle has become a tool of personal expression, a visible manifestation of individual identity and a metric by which ones status and standing in society can be conveyed to those we may wish to impress or with whom we desire to associate and belong. The ingredients required to construct a desired lifestyle are now for many, readily accessible and fall easily within their consumer grasp.

How consumers make that decision to choose one product over another has long been an objective of consumer research and with good economic justifications.

The promise of increased market success for those consumer centric business organisations is widely acknowledged and universally accepted (Schiffman \& Kanuk, 2015). The necessity for successful businesses to get into the minds of consumers and to understand how they make the purchase choices they do has spawned a myriad of consumer research approaches and accounts for a weighty percentage of many corporate marketing budgets. The rewards associated with comprehending the key factors which can influence consumer behaviour and purchase choice in any given situation are reflected in increased market share, long term customer loyalty and a healthier bottom line for those business organisations who manage to crack the consumer decision making code.

\section{Consumer Decision Making - How do Consumers Choose?}

The process by which consumers make decisions can be examined from a number of perspectives. Various models are put forward in the marketing literature as representing how 
consumer decisions are made. Interestingly the role played by the consumer themselves can vary substantially between some of the most widely referenced models.

According to the Economic model the consumer is characterised as a rational, fully informed decision maker who seeks out and researches all possible solutions in an effort to make the perfect information -led decision at all times. While the Passive Model depicts the consumer as one who is easily persuaded and almost completely submissive to the promotional efforts of corporate marketing; here the consumer is seen as somewhat irrational in their decision making and can be swayed and readily manipulated by the power of advertising.

Somewhere in the middle of these two extremes we find the Cognitive Model which portrays the consumer as a thinker, who actively seeks out products and purchase opportunities to solve problems and whose objective is to make satisfactory purchase decisions rather than perfect ones.

While others suggest an Emotional Model of the consumer to explain how their decision making occurs. Here decisions are primarily emotionally driven. In these cases the consumer is unlikely to carefully research and deliberate over decisions but will impulsively choose as a result of their mood when making the decision or their particular emotional state at the time (Lenehan, 2008).

Some early behavioural models depicts the approach consumers take when making their purchase decisions as primarily a linear process : One such representation is the Consumer Decision Process (CDP) model (see Figure 1), which was first developed by professors Engel, Kollat and Blackwell( also known as the EKB model) at the Ohio state University in the late 1960s. The CDP model suggests that consumers typically progress through seven distinct stages as they make their consumption decisions (Blackwell et al.,2001) The first stage of the Consumer Decision Process is called Need Recognition, where the consumer recognises some real or perceived gap between their actual and desired state and seeks to fill this gap through acquisition or purchase. The consumer then enters the next stage called Information Search, where they gather from a variety of information sources data to help them in their quest. The consumer must then begin to Evaluate the Alternatives from which they may choose. This leads to the fourth stage in this process, which is the act of purchase itself which is then followed by the Consumption stage. The next stage, PostPurchase Evaluation, is presented as one of particular importance in determining levels of customer satisfaction or dissatisfaction and the subsequent repurchase behaviour on the part of the consumer. The final stage proposed is that of Divestment, where the consumer will discard or pass on or may even recycle their purchase. 


\section{Main Stages of the Consumer Decision Making Process}

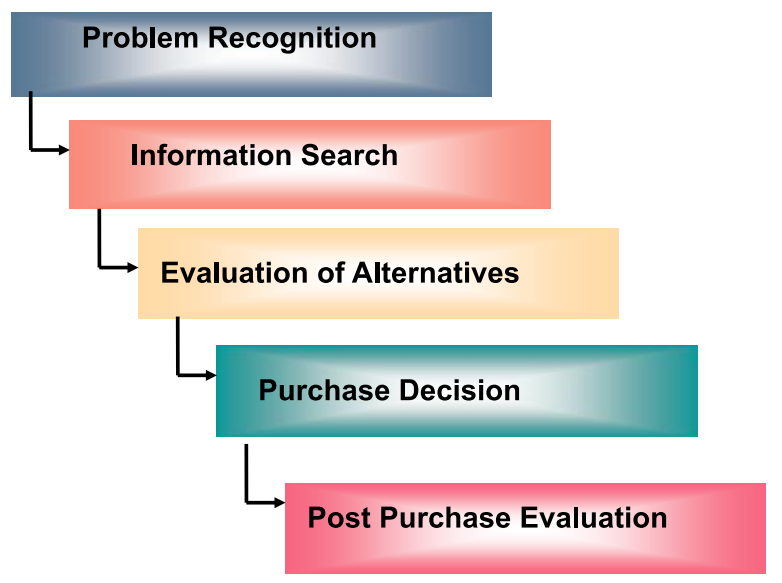

\section{Figure 1: Consumer Decision Process Model}

While the outlined CDP model provides a useful tool to analyse some consumer decisions it provides a rather narrow lens with which to view the complexities inherent in many consumption choices.

It is necessary to consider the role of consumer involvement in any purchase decision made: The involvement construct first proposed by Sherif and Cantril (1947), and which is measured from low to high, can be simply explained as a reflection of how important a particular decision is for the consumer; the involvement level may stem from a particular attachment or interest with the product itself, or it may be that the purchase situation/occasion is what lends greater importance to the purchase decision or the level of involvement may be associated with the reason for purchase or how the purchase will be consumed rather than the product itself or how it is purchased (Blackwell et al. 2001).

It is also important to understand that not all decisions are viewed in the same way by the consumer. While accepting that many consumer purchase decisions arise from a desire to solve some identified problem; Lenehan (2008), suggests that these problems can be depicted on a continuum which extends from the limited problem solving decisions, requiring less thought and time on the part of the consumer to solve to the more considered or extended problem solving decisions.

Extended problem solving decisions often represent those which the consumer feels less knowledgeable and secure about making on their own. They are often those where the consumer's level of involvement is highest (Schiffman and Kanuk, 2015). These occasions can often offer timely opportunities for marketing interventions on the part of a product/service provider. The provision of accessible information, guidance or even a reassuring testimonial or service guarantee can often win over the wavering or uncertain consumer faced with what they perceive to be a substantial and important decision. Many consumers prefer to simplify the decision making process for themselves through habitual purchase decisions where they repeatedly make the same purchase and consumption choices, staying loyal to particular products or brands and in so doing reduce or remove the necessity to invest as much in their decisions

(Zukin and Maguire, 2004). 


\section{Factors Influencing Consumer Wine Choice}

The broad consumption choices made by consumers are shaped by a number of factors. The determinants which most often influence these choices can be grouped within three main categories (Schiffman and Kanuk, 2015). Firstly there are Individual influences which differ from one consumer to another. These factors include personality, values and lifestyle, level of consumer resources, motivation, knowledge and attitudes. Secondly, the consumer is generally faced with a number of factors in their Environment which will exert an influence on their consumption choices. Influences can emanate from the consumer's own family and peers as well as from their social class and their cultural norms. The situational environment in which the decision is being made is also acknowledged as having an impact on the consumer's choice. Thirdly there are a number of Psychological processes which play an influential role in consumer decision making. These include the process by which consumers process information, reflecting how they receive, process and make sense of what is communicated to them and around them. How they as individuals change their knowledge and behaviour as a result of their past experience, in other words the psychological process of how learning occurs for them as individuals can also influence choices made (Lockshin and Corsi, 2012).

It is clear from much of the research on consumer decision making that the purchase and consumption choices consumers make can be influenced by a combination of individual, environmental and psychological factors. Research, specifically into wine consumers and their behaviour takes cognisance of these complex factors and has become increasingly sophisticated, now including explorations of consumer personality, levels of consumer involvement with wine and acknowledging the milieu of motivations behind consumers wine purchase behaviour (Hall and Mitchell, 2008).

The Australian winemaker's federation (2009) have long since acknowledged the special place wine holds in the lives of many consumers, suggesting that wine is more than just a beverage, that it has become a lifestyle product with a high degree of complementarity with food, hospitality and tourism as a whole.

It is this innate role in the lifestyles of many consumers which attracts the fascination of those such as Charters (2006) who proposes a triadic approach to the categorisation of wine consumption motivation; he suggests that consumers choose to consume wine for utilitarian reasons, for symbolic reasons and for experiential reasons, with utilitarian motives being of least importance.

Once we accept there are a number of drivers which motivate consumers to drink wine then it becomes clear that efforts to ascertain what can influence consumers choice of which wines to choose in any given consumption situation is hugely complex. However, this complexity should be viewed as a challenge rather than an obstacle for those in the wine business. The virtual matrix of criteria that such a combination of influences and consumption situations constructs provides countless sales opportunities for winemakers and marketers alike. The marketing implication is clear; the symbolic and experiential nature of wine consumption choices demands that those involved in the wine industry across all levels appreciate the pivotal role of experience in consumer decision making for lifestyle products such as wine. The wine tourism product is perfectly poised to fulfil this desire amongst wine consumers not just to drink wine but to truly experience and connect with their chosen wines. Those that are involved in developing wine tourism products must understand and strategically manage the wine tourists' experience they provide, if they are to maximise the impact of wine tourism on future wine purchase and consumption decisions. 


\section{Experiential Consumption and the Wine Tourism Experience}

Holbrook and Hirschman (1982:132) define consumption from an experiential perspective, describing it as "a primarily subjective state of consciousness with a variety of symbolic meanings, hedonic responses, and aesthetic criteria".

While Arnould and Price (1993) stress that providers within service industries must focus not just on delivering customer experiences but contend that to be truly impactful, the delivery of service experiences must be perceived as extraordinary by the consumer. In an era where competition is strong and service industries can struggle to set themselves apart, a focus on the provision of a unique customer experience can offer the elusive solution to this problem of differentiation (Fernandez, and Cruz, 2016). The role played by the consumer in the consumption of experiences is one of increased participation and control, in such service encounters service providers do not sell experiences, but instead they provide a basic platform which consumers then use to obtain their own unique experiences (Walls, 2013). There is evidence of an explicit need for the blurring of lines between the customers themselves and the service provider if truly extraordinary and memorable experiences are to be had by consumers.

The relationship between positive consumption experiences and future consumer intention is undeniable. Consumers are more likely to rely on their own prior experiences during their choice processing and decisions about future consumption behaviours (Kerstetter and Cho, 2004). It is also clear that levels of purchase motivation and levels of involvement with the product are higher when information is drawn from the individual's past experience (Kim, Richie and Tung, 2010). Not only are these recalled personal experiences regarded as more credible by the consumer but they are known to greatly influence future consumption behaviour (Hoch and Deighton, 1989).

The pivotal role of the consumer's immersion and involvement in the creation of their own consumption experience is accepted within the broad tourism literature .Tung and Richie (2011) refer to the customer as an essential part of the service offering where the customer is involved in the co-creation of their own experience. This experiential view of tourist consumption behaviours is particularly relevant to the wine tourism sector. Wine-related trips have emerged as a growing sector of special-interest tourism and are now regarded as playing an essential role in regional tourism development across many wine producing areas around the world. The original 4Es model (Expertise, Evaluation, Education and Experience) proposed by Pine and Gilmore (1998) has been widely applied to the wine tourism industry (Festa et al. 2015, Quadri-Felitti and Fiore, 2013), acknowledging the persuasive potential associated with a positive wine tourism experience and the wine tourists subsequent wine consumption decisions.

\section{Wine Tourism and Consumer Wine Choice}

Getz (2000) describes wine tourism as a form of special interest travel based on the desire to visit wine producing regions or where travellers are encouraged to visit wineries and wine producing regions while travelling for other reasons. It is important to recognise as Getz does that for some, the primary motive for their wine tourism activities is indeed the wine and those wine related events but for others, participating in wine tourism activities is another part of their tourist experience while on holiday or travelling for whatever reason. From a marketing perspective, this is an important exercise in segmentation, supporting the view that 
not all those who engage in wine tourism do so for the same reasons and therefore the expected outcomes of their exposure may also vary.

Various typologies of wine tourist are presented, Charters and Ali-Knight (2000) differentiate between the "wine lover" who has a comprehensive grounding in wine education and primarily visited wineries to enhance their general wine knowledge and the "wine connoisseur" who has a more specific interest in wine and particularly in its production. Johnson (1998) similarly differentiates between the "generalist" wine tourist and the "specialist" wine tourist, while acknowledging the more ephemeral appeal that wine regions can have for tourists. The aesthetic and experiential appeal of many wine regions projected or perceived image as a rural paradise is for some a greater initial attraction than the specific wine related motives (Williams, 2001).

Local food and wines are some of the main products which are highly related to country of origin and to the tourism experience; as locally produced offerings contribute to the uniqueness of a tourist experience, they have become critical to many successful tourism destinations (Alamanos et al., 2016). Lee and Lockshin (2011) examined the relationship between the image held by tourists of a destination and how this image influences their perceptions of that country's produce. Their findings indicate that a favourable destination image leads to a positive belief about the quality of products and brands emanating from that destination. Specific research into the post visit consumption behaviour of tourists, has shown a positive relationship between their perception of food and wines from destinations they have visited (Chaney, 2002). Mitchell and Hall (2004) also found that visits to wineries can predispose visitors to long term loyalty; this positive correlation between tourist participation in wine related activities such as wine festivals (Houghton, 2002) and their post activity consumption shows that wine tourism experiences can and do influence consumer wine choices. In relation to wine tourism in particular, Brown and Getz(2005) go further and suggest that consumers who visit a particular area and taste its wine, can become loyal or frequent consumers of those wines themselves, but often actively promote the wines of the area visited to others becoming unofficial brand ambassadors for the wines.

In some respects this is hardly surprising as wine is a product that has an affinity with its place of origin possibly more than any other in the minds of those who produce it and those who ultimately purchase and consume it. It is both regulated and marketed on the basis of where it comes from (Famularo et al., 2010). Many retailers display their wine by country and region of origin and many consumers simplify their wine choices by picking them on the basis of country of origin (Chaney, 2002). The perception of wine quality, particularly in traditional wine production regions, is more closely aligned to the concept of terroir than any other factor of its production.

The literature reviewed here clearly identifies the complexity of wine consumers decision making processes and acknowledges the relationship wine consumers perceive between a wine and its place of origin. The power of that perceived relationship to influence consumer wine choice underpins the research study outlined below. The impact of consumers' experiential involvement with wine tourism activities is empirically investigated and the results are presented and discussed in the next section of this chapter.

\section{Background to the Study}

While Ireland has a long and historic association with the production of alcoholic beverages such as Irish whiskey, Baileys cream liqueur and most famously Guinness stout, it is not known for its wine production. However wine accounts for over $27 \%$ of all alcohol consumed in Ireland (Irish Wine Association, 2016). Interestingly, these consumer figures show that Irish consumers are now opting for higher priced and higher quality wines. Irish wine 
consumers choose wines from all over the world; Chile and Australia rank up there with France, Spain and Italy amongst the favoured countries of origin for Irish wine drinkers. It is perhaps because Ireland does not have a tradition of commercial wine making itself that Irish consumers feel free to choose wines from all over the globe without fear of appearing unpatriotic. But are consumers wine choices in any way influenced by their travel and tourism experiences and if so, how and for how long? The research undertaken seeks to explore this question in more detail.

\section{Research Methodology}

A qualitative research study was conducted amongst a sample of wine consumers living in Ireland. The main aim of the study was to investigate the influence of holidaying in wine producing countries on consumers' subsequent wine purchase decisions. A number of research objectives were set for the study. The first was to ascertain if consumers felt their wine choices were influenced by their own past wine tourism experiences. Secondly the research sought to establish if having visited wine producing regions, consumer's level of involvement with the wines of those regions or countries had changed. The third research objective centred on consumer loyalty; seeking to determine if in the long term, consumers were still more likely to choose wines from wine producing countries they had visited in the past.

A qualitative approach to the research was taken. Information was gathered through the use of in- depth semi-structured interviews. Each participant was interviewed in person. An interview protocol sheet was developed and used to guide each interview however participants were allowed and encouraged to dictate the flow of the interview to optimise the qualitative nature of the responses. Interviews were carried out over a four day period. All interviews took place in Dublin city. Interviews lasted on average one hour long. Each interview was recorded with the interviewee's permission and all interviews were subsequently transcribed for analysis. Interview data was analysed under the three main themes identified in the study objectives and under which the results are presented and discussed below.

A convenience sample of 12 participants was used in the study. Two essential criteria qualified interviewees to participate; firstly that they were purchasers and consumers of wine and secondly that they had experienced some wine tourism activity. Initial participants were selected by the researcher and others were selected though referrals and recommendations. The sample was made up of five males and seven females. All those sampled were aged over 18 with ages ranging from 38 to 61 years old. All participants were in full time employment. Two of those sampled worked in administration, while another two worked in the area of finance. Four of the sample worked as academics and the remaining four worked in the hospitality sector. All respondents were wine drinkers and had self-identified as having varying levels of involvement with wine. Each member of the sample holidayed abroad at least once each year and each stated a preference for holidaying in warm countries that had lots of sunshine. All had holidayed in or travelled to wine producing countries and had taken part in wine tourism activities while in those countries. The wine tourism activities experienced by the sample population included visits to vineyard areas, participating in winery tours and taking part in tastings of locally produced wines. 


\section{Results and Discussion}

The results of the research study carried out are presented and discussed below. The findings are presented under the three main research objectives set for the study. The qualitative nature of the experiential focus of the research is evidenced by the words of the interviewees giving voice to their responses.

Firstly interviewees' responses discussing how their wine tourism activities have influenced their subsequent wine choices are presented. Secondly participant responses referring to their levels of involvement and how these have changed as a result of their wine tourism activities are discussed. Finally responses relating to participants long term loyalty towards wines of regions or countries first encountered while on holiday are presented.

\section{Wine tourism as source of influence}

In line with previous studies suggesting that wine tourism activities should largely be viewed as part of or an enhancement of the holiday experience (Brewer and Alant, 2009), the research here also found that trying new wines and learning about wines from the holiday destination through vineyard visits and local wine tastings was perceived by the participants as an essential part of their holiday experience. "How we got into Spanish wines was from travelling really, from going on holidays to Spain and trying out the local wines and seeing how the grapes were grown and then trying to find those wines or something similar from Spain when we got home" P6. Some respondents felt that becoming familiar with the wines of the region was an integral part of their holiday experience. In particular they felt that developing a knowledge of the styles of wine produced and how they tasted contributed to the enjoyment and rituals they associated with the holiday experience. "One of our favourite things to do when we first arrive is to visit one of the local wineries and get to know some of the wines of the area"P8.

"We would be into going to the local restaurants when we're on holidays and trying the local wines they recommend, for us it's just part of being on holiday" P11. Interestingly all participants perceived a definite link between wines and wine regions they encountered while travelling and the wines they liked to consume at home. Consistent with the views of Kerstetter and Cho (2004), the findings demonstrate that how consumers often rely on their own past experiences to influence their consumption choices. The memories and positive experiences consumers recalled from their wine tourism activities were used as information sources by consumers when making their post-holiday wine choices. "Recently we were in Portugal and we came across some lovely wines there and so yes I tried a couple of Portuguese wines when I got home" P5. In fact for some, the emotional responses felt to the experiences they had were so strong that they acted as a driver to seek out the particular wines they had found. "First time I went to Melbourne, I had the most amazing wines and for days afterwards we were all talking about them and even when we came home I purposely went to find some of those wines" $P 4$.

\section{Impact on wine involvement level}

Even those participants who did not consider themselves wine experts or wine buffs displayed a keen interest in trying out and recommending to others wines from their holiday experiences. Just as Brown and Getz (2005) suggest, consumers often feel so strongly about the wines they have experienced themselves that they actively promote those wines and wine 
regions to others on their return from holidays. "It's moved on from holiday photographs to sitting down over a bottle of wine that we had abroad and talking about the winery where we tasted it and where you can get it here and how much more expensive it is here at home" P12. These findings support those of Robinson and Getz (2016) who highlight the social bonding dimension experienced by tourists and how their sense of connection to places visited is often intensified though their food and wine tourism activities. In line with the findings of Festa et al. (2015) and Quadri-Felitti and Fiore (2013), participants in this study spoke of the connection they felt with particular wines having visited those vineyards and having seeing those wines being made. "We went through the vineyards and you saw the whole process all that really resonates with you. It really makes the whole experience more important, all that stays with you and gives you a really good appreciation of all the work that goes into the wine" P4. During the interviews, participants spoke of the effect some of what they had seen and experienced had on them and how they felt and thought about the wines as a result. "Spain had an impact on me because I think their wines have really improved, and we have been going to Spain for years, but now the quality and variety has really improved" $P 8$.

\section{Long-term Loyalty}

Consistent with the view of Alamanos et al., (2016), the findings highlight how wine tourism activities strengthened consumers' sense of connection between the wines and their place of origin. "It's very enjoyable to drink the local wines, it's of the place, it's like eating vegetables from someone's own garden at their house, it's special" P3. The research suggests that long term consumer loyalty towards wine of a particular region or country is developed through their holiday experiences and shows that consumers continue to choose wines from regions and countries they have visited long after their holiday. "Personally if I go to a supermarket and see Chilean wines, I will still choose them; because after being there and seeing it, I know it's going to be good" P1. Tung and Richie (2011) found that wine tourism activities constitute an experience, not merely to be provided for the consumer, but involving the consumer themselves as a co-creator and re-creator of that experience, each in their own unique way. These findings reiterate those views, highlighting that the connection felt by some consumers between their wine tourism activities and the consumption of those same wines at home at a later time was so strong that they actively used those "holiday wines" as a means of recreating the holiday feelings and recalling their holiday memories long after their return. "I suppose it's more of a reminiscence experience, you're not on your holidays but still for me it still brings back a bit of that holiday feeling "P8. This study highlights the enduring nature of the loyalty developed by consumers through their personal wine tourism activities towards the wines and wine regions experienced. For some, those wines first encountered on holidays represent their "go to wines" even years after first encountering them. "I would still drink wines that I found on holidays years ago, I still look to Spain for the reds" P6.

\section{Conclusion}

There is no such thing as one undifferentiated wine market nor is there a typical wine consumer (Hall and Mitchell, 2008). Instead the wine market is made up of several, sometimes very niche, segments that are influenced by demographics, psychographics and the situation in which the wine is being consumed. While wine price, region of origin, grape 
variety and brand are amongst the most frequently mentioned extrinsic cues that can influence wine consumers (Chrea et al., 2010). Information consumers hold about the country from which the wine originates generates expectations relating to the image of the country, which in turn influences beliefs about the attributes of the wine itself (Williamson et al, 2016). In fact for a luxury product such as wine, country of origin information has a greater effect on consumer decision making both at higher involved wine consumer (Lockshin and Corsi, 2012) and for those who are within the new to wine consumer markets (Perrouty et al,.2006 ). Therefore as this study shows, the wine tourism experiences which consumers have, present an invaluable opportunity for wine producers and wineries to develop an enduring sense of involvement and loyalty amongst its visitors which in turn can translate into positive and emotive stimuli when subsequent wine purchase decisions are being made by those consumers. Not only this but, those consumers often become ambassadors for those wines and wine regions, actively praising and promoting them to others.

\section{Implications for Theory and Practice}

Not all countries produce wine, not all tourists come from a culture of vine growing and wine making. Not all consumers belong to a society where there is a historical association with the pressing of grapes and the vinification of their juice, however as consumers, they can still embrace the wine lifestyle so many desire to associate with and so for them wine tourism can represent a glimpse into a mysterious and idyllic other existence associated with their special times whether spent relaxing on holidays or socialising at home.

The study findings clearly illustrate the links made by consumers between their wine tourism experiences and their subsequent wine purchase preferences. The role of wine as a means of evoking, recalling and recreating holiday memories is evident and emphasises the importance of facilitating the co-creation of memorable experiences by wine tourism providers. The findings highlight the potential strategic marketing opportunities for wine tourism to contribute to long term consumer loyalty through continued purchase of wines first experienced as a wine tourist. These findings also highlight the long term positive impact of the emotional recollection and evocative associations displayed by respondents between the wines encountered and their continued use of these wines as a means of remembering past holiday experiences.

This study contributes important findings not only to those involved in the wine tourism industry as highlighted above, but also strengthens the theoretical contentions around the pivotal role of consumers personal experiences in the consumer decision making process. The findings also support the experiential consumption perspective as a means of developing a deeper understanding of consumer motivation when making their purchase choices. 


\section{References}

Alamanos, E., Kuznesof,S. and Ritson. C. (2016) The Influence of holidays on wine purchasing behaviour: marketing and tourism insights based on a holiday experience in Greece. International Journal of Tourism Research. Vol 18 (3) pp. 228-235

Arnould, E.J. and Price, L.L (1993), “ River magic; extraordinary experience and the extended service encounter", Journal of Consumer Research, Vol.20;1, pp 24-45

Baudrillard, J. (1998) The Consumer Society: Myths and Structures. London: Sage.

Blackwell, R. , Engel, J. and Miniard, P. (2001) Consumer Behaviour, 9th Edition. Ohio. South- western.

Brown, G. and Getz, D. (2005) Linking wine preferences to the choice of wine tourism destinations. Journal of Travel Research. Vol. 43 (February) pp. 266-276

Brewer, J. and Alant, K. (2009). The Hedonic nature of wine tourism consumption: An experiential view. International Journal of Wine Business Research.21. (3).pp.235-248.

Charters, S. (2006) Wine \& Society. The social and cultural context of a drink. ButterworthHeineman. Oxford.

Charters, S. and Pettigrew, S. (2008), Why Do People drink Wine? A consumer-Focussed Exploration. Journal of food Products marketing. Vol. 14 (3), pp13-32.

Chrea, C., Menlo, L., Evans, G., Forde, C.,Delahunty, C., and Cox, D (2010), An investigation using three approaches to understand the influence of extrinsic product cues on consumer behaviour: an example of Australian wines. Journal of Sensory Studies, Vol.26, pp. 13-34.

Famularo, B., Brewer, J. and Li, E. (2010) Region of Origin as choice factor: Wine knowledge and wine tourism involvement influence. International Journal of Wine Business Research. Vol.22 (4) pp362-385.

Featherstone, M. (2007) Consumer Culture and Postmodernism. London: Sage. Fernandes, T., and Cruz, M. (2016) Dimensions and outcomes of experience quality in tourism: The case of Port wine Cellars. Journal of Retailing and Consumer services. Vol. 31 .pp 371-379.

Festa, G., Cuomo, M., Metallo. G, and Festa. A. (2016) "The (r) evolution of wine marketing mix: From the 4Ps to the 4 Es." Journal of Business Research. 69. Pp.1550-1555. 
Getz. D. and Carlsen,J. (2008 )Wine Tourism among generations X and Y. Tourism. Vol.56 (3) pp.257-269

Getz, D. (2000). Explore Wine Tourism: management, development and destinations. New York: Cognizant Communications Corporation.

Hall, C. Michael and Mitchell, R. (2008.) Wine Marketing: A practical guide. Butterworth Heinemann, Oxford

Hoch,S. and Deighton, J. (1989). Managing what consumers learn from experience. Journal of marketing, 53 (April), pp 1-20.

Holbrook, M.B. and Hirschman, E.C. (1982), "The experiential aspects of consumption: consumer fantasies, feelings and fun", Journal of Consumer research, Vol.9; 2, pp132-142.

Helkkula, A. (2011) "Characterising the concept of service experience", Journal of Service management, Vol.2; 3 .pp.367-389

Jaeger, S., Danaher. P., and Brodie. R. (2009) Wine Purchase decisions and consumption behaviours: Insights from a probability sample drawn in Aukland, New Zealand. Food Quality and Preference. Vol.20 .pp. 321-319.

Jamal, A. (1996) Acculturation: The symbolism of ethnic eating among contemporary British consumers. British food Journal, 98(10), 12-26

Kerstetter,D. and Cho,M. (2004) Tourists information search behaviour: The role of prior knowledge and perceived credibility. Annals of Tourism Research, Vol.31 (4) pp.961-985.

Lenehan, M. (2008) Consumer Behaviour: Irish Patterns and Perspectives. Dublin. Gill \& Macmillan.

Lindgreen, A., Vanhamme, J. and Beverland, M.B. (eds) (2009) Memorable Customer Experiences: A Research Anthology. Surrey: Gower.

Lockshin,L. and Corsi, A.M. (2012). Consumer behaviour for wine2.0: A review since 2003 and future directions. Wine Economics and policy.1. pp. 2-23.

Lockshin,L. and Hall,J. (2003). Consumer purchasing behaviour for wine; what we know and where we are going. Adelaide: International Wine Marketing Colloquium. 
Perrouty,J. , d'Hauteville,F. and Lockshin, L. (2006). The influence of wine attributes on region of origin equity: An analysis of the moderating effect of consumers perceived expertise. Agribusiness. Vol.22.pp.323-341.

Pine, B.J. and Gilmore, J.H (1998).Welcome to the experience economy. Harvard Business Review. July, pp. 97-105.

Quadri-Felitti, D. and Fiore, A. (2013) Destination loyalty: Effects of wine tourists' experiences, memories, and satisfaction on intentions. Tourism and Hospitality Research. Vol 13 (1) pp. 47-62.

Robinson, R.N.S. \& Getz, D. (2016). Food enthusiasts and tourism: Exploring food involvement dimensions. Journal of Hospitality \& Tourism Research, 40(4). pp.432-455.

Sheriff, M. and Cantril, H. (1947). The Psychology of ego involvement. New York: Wiley.

Schiffman, L. and Kanuk, L. (2015) Consumer Behaviour, Global Edition, Pearson.

Walls, R. (2013). A cross-sectional of hotel consumer experience and relative effects on consumer values. International Journal of Hospitality management. 32; 179-192

Winemakers Federation of Australia (2009). "Harnessing the tourism potential of wine and food in Australia; A strategic Framework for the future of wine and food tourism to 2020"

Williamson, P., Lockshin, L.Leigh, F.and Loose, S. (2016). Influencing Consumer choice: Short and medium term effect of country of Origin information on wine choice. Food Quality and Preference. 51. Pp. 89-99.

Zukin, S., and Smith Maguire, J. (2004). Consumers and Consumption. Annual review of Sociology, Vol.30; 173-197 